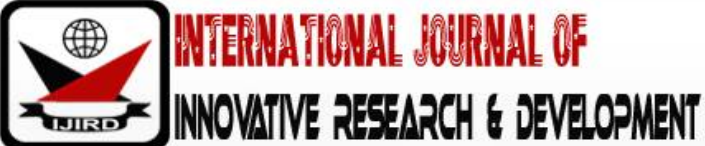

ISSN 2278-0211 (Online)

\section{Realism in the Study of International Relations: A Theoretical Consideration}

\author{
Dr. Mujitaba Liman Arabu \\ Lecturer, Department of History, Usmanu Danfodiyo University, Sokoto, Nigeria \\ Umar Aminu Yandaki \\ Alumni, Department of History, Usmanu Danfodiyo University, Sokoto, Nigeria
}

\begin{abstract}
:
Despite being an aggregate of the numerous events and issues that summates the relationships among world nations, the study of International Relations could be best undertaken through the instrumentality of theories. Theories provide an intellectual with the ability to critically, logically and coherently sort international interactions and digest them to manageable categories for appropriate comprehension. This differentiates the study of International Relations as an academic discipline from its laymen view. Considering the indispensability of theories in the study of International Relations, therefore, this paper studied Realism as an important theory in the analysis of international interactions. Having scrutinised its meaning, development and contributions to discipline, the paper argued that Realism is invaluable in the study of International Relations. However, considering its pitfalls, the paper submitted that despite its importance, it should preferably not be the sole lenses for the interpretation of international interactions.
\end{abstract}

Keywords: Realism, theories, international relations

\section{Introduction}

The application of theories in the study of International Relations is the surest epistemic strategy one could deploy to master the flexibilities and complexities of international system, structures and interactions - from intercitizenry level to that of national governments. This is more so because as much as the indispensability of empirical knowledge in theorisation thrives, the empirical knowledge could not be epistemologically comprehended, unless when premised on propositions, hypothesis and theories on the already known or established pattern of human conditions (Yandaki, 2015: 11-12). Indeed, the fluidity and flexibility of knowledge as it endlessly flows from the fountain of human intellect makes schools of thoughts and streams of interpretations to be numerous. This is not unconnected to the fact that people are usually the conscious or unconscious spokespersons of their society, as it profoundly influenced them (Carr, 1984; 55). As such, it is understandable why scholars belonging to different schools of thought, often write on the same phenomenon, differently.

Impliedly, therefore, theories, regardless of the academic usefulness of their abstractness must possess empirical roots and correspondence (Yandaki, 2015: 14); so too, the theories in International Relations, the dominant among which are Realism, Liberalism and Marxism. These are considered to be the dominant because 'whatever comes later is simply built on them' (Arabu, 2016: 43). These schools of thought or theories are a construct of an array of scholarly dispositions by different thinkers, both classical and contemporary, on the nature and essence of human behaviour and interactions as they affect International Relations. The prime goal has been to have a cognitive mastery over the patterns of human relations in order to explain the laws of international interactions or recurrent national behaviour and orchestrate a safer and more prosperous world. Thus, being a plethora of enormous and complex events, issues and relationships, International Relations could be best understood and analysed through the instrumentality of theories, which help......observer to think critically, logically, and coherently by sorting these phenomena (i.e. the complex events, issues and relationships) into manageable categories so that the appropriate units and level of analysis can be chosen and, where possible, significant connections and patterns of behaviour identified (Burchill and Linklater, 2005: 16).

Trying to assemble, narrow and explain the complexities of the nature of human beings as they interrelate, representing their respective groups at an international level, for instance, the liberalists stressed on the use of liberal approaches in international interactions. Furnished with a firm optimism on human nature, they believe that international law and morality, rather than power (à la the realists), are the key influences on International Relations; and with the presence of International Organisations such as United Nations (UN), cooperation, peace and prosperity could be achieved to form a comity of nations. The Marxists on the other side solely view International Relations from the perspective of economy, class struggle and the control of productive forces. They conclude that the hierarchical nature of the international system, which favours some nations at the expense of others, was a result of imperialism (Mingst, 1999: 66$70 \& 79-83)$. 
Nonetheless, the focus of this paper is on Realism. This paper contends that although, realism has some limitations, it is an essential lens through which International Relations could be viewed, comprehended and analysed. The aim here is, thus, to define realism as an explanatory theory, identify its major proponents and their philosophical-cumtheoretical postulations on the nature and essence of human nature as it affects International Relations. The paper also provides a critical assessment of some of the major arguments that inform the realists' perspectives of International Relations.

\section{The Concept of Realism}

As a concept, Realism is used differently in different disciplines. In philosophy, for instance, it is widely used as an ontological theory, opposed to idealism and nominalism. 'Scientific Realism', on another pace, is a philosophy of science opposed variously to empiricism, instrumentalism, verificationism and positivism. In literature and cinema, also, the concept of Realism is opposed to romanticism and the 'escapist' approach (Donnelly, 2005: 29). However, the type of Realism, which is the primary focus of this paper, is termed 'Political Realism', also known as realpolitik (power politics). Although its application in the understanding of International Relations is a later development, Political Realism is a product of centuries-old philosophical traditions. In International Relations, Realism is a tradition of analysis that stresses on the study of how sovereign entities uses politics with power to pursue and protect their national interests, even if that means threatening one another with military, economic or political aggression (Donnelly, 2005: 29). It is, therefore, obvious that Political Realism, despite its clear family resemblance with the above mentioned various forms of the concept (as informed by their commonality in a concern for fact and reality and rejection of impractical and visionary), have no necessary connections with them.

Realism in International Relations is an explanatory theory, as opposed to constitutive. Explanatory theories are used to make empirical knowledge more intelligible as it attempts to make a better sense of the actors, structures, institutions, processes and particular institutions; so too, Realism is a paradigm used to make International Relations more intelligible. As such, its hypothesis is susceptible to tests in begging for casual explanations with the view of identifying the major trends in International Relations (Burchill and Linklater, 2005: 15). As it affects the study of International Relations, Realism as a theory lacks a single universally accepted definition. The details in its definition differ depending on how it was viewed by different scholars. Despite these differences, however, the various definitions given to the theory have one unique fact about them, which resides in the quite distinctive and recognisable flavour they all possess. This is because, they all laid much emphasis on politics imposed by human (and by extension, national) selfishness (egoism) and the prevalence of anarchy (perhaps, due to the absence of international government), which informs the primacy of power and security for all nations to defend and promote their (selfish) interests. At the same time, their major hallmarks lies in the primacy they give 'rationality' and 'state-centrism' in international interactions (Donelly, 2005; Mingst, 1999).

In other words, Realism could be viewed as a theory of International Relations which views international interactions, which themselves are colossal and bewilderingly complex, from the perspectives of an intense political struggle for power. As observed by Mingst (1999: 71-79), the theory perceive Individuals and States as primarily selfish and power seeking. The States are also perceived as unitary actors in the pursuit of their national interest, which unavoidably traps them into an anarchical situation. As such, the Realists views the International System, which itself constitutes a set of rules structured according to some established rules and pattern of international interactions (Arabu, 2018: 41), as anarchical in nature; and consequently, the need for the management of insecurity which arises out of the anarchical system. The Realists are known advocates of rationality in decision making and reliance primarily on balance of power and deterrence to keep the international system intact and as non-threatening as possible (Mingst, 1999: 71).

\section{The Major Proponents of Realism and their Thoughts}

As mentioned earlier, Realism, just like any other theory, is a construct of variety of dispositions by various philosophers, both classical and contemporary. As such, it is widely divided into two major categories, i.e. Classical Realism and a series of contemporary re-interpretations of the theory, the most popular among which is Structural Realism. While Classical Realism is a product of ancient philosophical traditions, the recent re-interpretations of Realism, including Structural Realism are recent developments that became widely known during the $20^{\text {th }}$ century.

Classical Realism is generally informed by the thoughts and writings of such classical philosophers and thinkers as Greek's Thucydides, Italian's Nicollo Machiavelli and English's Thomas Hobbes, the authors of History of the Peloponnesian War, The Prince and Leviathan respectively. It is, therefore, understandable that the philosophical dispositions that makes up Classical Realism predates the study of International Relations, as it only emerged as a discipline after the Second World War (Arabu, 2016: 43). As such, it should not be surprising that in various arguments concerning Classical Realism, especially those advanced by classical philosophers, emphasis was given on the nature and behaviour of human beings rather than States. Anyway, the behaviours of States are simply a replica of the behaviours of the people who controls them. As for the various re-interpretations of Realism in the $20^{\text {th }}$ century, they were championed, variously by scholars like Morgenthau, Kennan, Neibuhr, Waltz and E. H. Carr, etc. (Donelly, 2005).

Of course, for someone who is new to the theory, the obvious diversity, as could be observed above, can be frustrating, having different scholars from different backgrounds, categorised under different camps and each presenting peculiar albeit similar views concerning the same theoretical tradition. But as brilliantly cautioned by Burchill and Linklater (2005: 18), 'there is nothing abnormal about differences of perspective within the same theoretical tradition. Heterogeneity is a strength and an obstacle to ossification'.

To start with Classical Realism, one of its major proponents was the Greek philosopher, Thucydides, who lived between c. 460 BC and 400 BC. Most of his views about International Relations were deducted from his masterpiece, 
History of the Peloponnesian War, which is a canon of knowledge about the history of barely 30 years' war between Peloponnesian League (led by Sparta) and the Delian League (led by Athens) (Mingst, 1999: 71). From his experiences with the inter-state relations between the two Greek City States of Athens and Sparta, which was largely characterised by the use of power to (violently) pursue and protect national interest, Thucydides, came up with some four basic assumptions that are known as the basis of his understanding of International Relations.

First, that the state is the principal actor in International Relations rather than other international institutions. Secondly, he assumed the state as a unitary: 'although there may be debates among different officials from the same State, once a decision is made to war or capitulate, the state speaks and acts with one voice' (Mingst, 1999: 71). Thirdly, typical of many Greeks, Thucydides believed that individuals are rational beings, as such, the decision makers of a state are rational: 'they make decisions by weighing the strengths and weaknesses of various options against the goals to be achieved' (Mingst, 1999: 71). Lastly, he was known for his penchant on the essentials of the security of a state, as the surest strategy to deal with both foreign and domestic enemies, amidst an endless struggle for selfish promotion and protection of national interests in International Relations. For Thucydides, a state could enhance its security by doubling its domestic capabilities, especially with respect to economic development and forming alliances with other states with whom it shares interest. In fact, both before and during the Peloponnesian War, Thucydides observed that the fear of a rival was an essential factor that motivates states to join alliance (Mingst, 1999: 71-72). Indeed, this is true of International Relations even much later, especially during the First and Second World Wars, as well as the Cold War.

Another great thinker who exhilaratingly contributed to Classical Realism is the Italian philosopher, Niccolo Machiavelli (1467-1527). The thoughts of Machiavelli on politics in human (and by extension, states') relations, as demonstrated by his seminal work, The Prince, are tailored towards a basic understanding of the relationships as flourishing based on an extremely competitive system. As such, power politics serves as the basis of his understanding of the complex political system that informs International Relations; and this (power politics) determines the characteristics of all the competitors (individuals and states) in surviving it (Deutsch, 1978: 50). Indeed, Machiavelli's conception of International Relations could be aptly summarised by some suggestions he offered about the Prince (presumably, here, the Prince means 'state'), thus...

A prince who did not wish to lose his realm... always had to think and act in terms of power. He had to hoard and increase his resources, not dissipate them; to strive to enhance his own power and prestige and to diminish those of his competitors; to keep the common people passive and content, but willing to fight loyally at his command; to rule by force and fraud, being admired and feared but not hated; and to keep or break his words in quick accordance with whether loyalty or perfidy at any moment would more enhance his power.

A prudent prince, he continued,

Should never be neutral in a war among his neighbours, for if he let his weaker neighbour be defeated by some other prince, the strengthened victor would then turn to him. If he helped his weaker neighbour, however, they might jointly defeat the stronger neighbour who was the greater threat to both of them. Or thus allied, even if defeated, the two weaker princes might at least be allies in misfortune. Generally, however, today's ally is tomorrow's enemy, and one's strongest ally is one's greatest threat, for a prince promoting another's power, ruins his own (Deutsch, 1978: 50).

In a nutshell, it is observable from the above that Marchiavelli has a firm belief in state's promotion and protection of interests, even at the expense of whosoever. Profound in his belief for the existence of a highly competitive system of relationships among individuals and states, it could be argued that Machiavelli believes in the existence of anarchy in the international system. By extension, therefore, he believed in the promotion of alliances and various offensive and defensive strategies to protect the state (Mingst, 1999; 75).

The English philosopher, Thomas Hobbes (1588-1679), is another important contributor to the theoretical tradition that informs Classical Realism. Most of Hobbes's thoughts on human nature and International Relations were identified from his Magnum Opus, Leviathan. Hobbes began expressing his thoughts on individuals (and states) with discussions on the 'state of nature'. To him, men (and by extension states) are by their nature, equal in the body and mind: 'though, a man could manifest stronger in body or possess a quicker mind than some others, the difference between man and man is not considerable, as one man can thereupon claim to himself any benefit to which another may not pretend, as well as he. For as to the strength of body, the weakest has strength enough to kill the strongest either by secret machination or by confederacy with others that are in the same danger with himself' (Abel, 2004: 435-436). The case is not much different with states even in the later years. Each claiming its sovereignty, many apparently weaker states have proved to, at least, rise above strong states' control. One could take Cuba against the United States during the Cold War, Vietnam resistance war against the US (1955-1975), and the contemporary power and influence of Israel in International Relations, as food for thought.

Inherent from this equal feeling (i.e. equality in sovereignty), Hobbes believed, three principal phenomena would ensue: these are competition, diffidence and glory. Men (states) that are equal naturally have equality in hope, which would drive them to desire the same thing which they cannot both enjoy. Then, competition ensues, and that would make them become enemies. Once they become enemies, diffidence follows. With mistrust, individuals (states) invade for gain, safety (as in to crush the enemy, and, therefore be safe), and reputation (Abel, 2004: 236-237). Impliedly, in a situation, whereby men (states) relates with distrust and offensive invasions (with the sole aim of pursuing national interest), it becomes clear that the conjunction of the above identified conditions would produce an anarchical system of relationship. To Hobbes, therefore, states interact in anarchy. According to him, this anarchy leads to a war of all against all. And this happens in the absence of a common power - 'Leviathan' (or in the context of this paper, international authority) (Abel, 2004). This, according to him, could be best arranged through a social construct, when people (states) thought they would be more secured if they transferred their rights to a common power, so there could be law (in this context, International 
Law). Then, there would be justice and injustice, as well as many other regulations in interaction, which are all absent in the state of nature. Hobbes believes that in the state of nature, life is solitary, poor, nasty, brutish and short (Moore and Bruder, 2005: 314-319).

Moving down to the $20^{\text {th }}$ century, new interpretations on Realism were developed by various scholars. One of the most important among such scholars was the English historian, diplomat and international relations theorist; Prof. E. H. Carr (1892-1982), the author of The Twenty Years Crisis. Another important scholar that contributed to the development of the realist school of thought during this period was Hans J. Morgenthau (1904-1980). An emblematic figure in the study of International Relations, Professor Morgenthau, the author of Politics Among Nations, was widely considered, along with George F. Kennan and Reinhold Niebuhr, as one of the three leading American realists of the post-World War II period (Britannica: retrieved online). In fact, the study of International Relations, which began in the post-war years, was itself was believed to have begun as a theoretical discipline (Burchill and Linklater, 2005: 1). And the works of Carr and Morgenthau, i.e. The Twenty Years Crisis and Politics Among Nations were believed to be foundational texts in the field for three major reasons, thus,

Each developed a broad framework of analysis which distilled the essence of international theory from a disparate events; each sought to provide future analysts with the theoretical tools for understanding general patterns underlying seemingly unique episodes; and each reflected on the forms of political action which were most appropriate in a realm in which struggle for power was pre-eminent (Burchill and Linklater, 2005: 1).

In these seminal books, the authors, against the background of their time, which was dominated by the crisis, traumas and hopelessness that characterised the periods during the First and Second World Wars, as well as the inter-war years in between; and also the dominance of Liberalist traditions, they rose and challenged the status quo. They were both...

...motivated by the desire to correct what they saw as a deep misunderstanding of the nature of international politics lying at the heart of the liberal project - among them the belief that the struggle for power could be tamed by international law and the idea that the pursuit of self-interest could be replaced by the shared objective of promoting security for all (Burchill and Linklater, 2005: 1).

Far from preaching the gospel of relentless struggle for power and security in International Relations, the emphasis of Carr and Morgenthau remains that the reform of international system, which ignored the struggle for power would forever be a white elephant job: 'they maintained the liberal inter-nationalist world view had been largely responsible for the crisis of the inter-war years' (Burchill and Linklater, 2005: 1).

These scholars equally believed in quite a number of the submissions of Classical Realists. Morgenthau, for example, maintained that International Relations could be best understood with the prism of power struggle. He explained struggle for power at three levels of analysis. First, in the style of Hobbes, he believed in the flawed individual in the 'state of nature', characterised by egoism, selfishness and an immense struggle for self-preservation. Secondly, he firmly believed that autonomous and 'unitary state' (à la Thucydides) is constantly involved in power struggles, balancing power with power and reacting to promote and protect what it considers as its national interest. And finally, he supported the idea that the international system is anarchic; and since there is no higher power to put the competition to an end- the struggle is continuous (See Morgenthau, 2012; Mingst, 1999: 76).

However, in 1979, a new impetus was given to the theory by the rise of a popular reinterpretation of Realism termed Structural- or Neo- Realism, championed and delineated by Kenneth Waltz (1924-2013) in his popular work, International Politics. Generally, the neo-realists see the international system structure as the most important unit to study rather than the individual (state), who is labelled to be selfish and power seeking. This structure, the neo-realists argued, is determined by the ordering principle viz, the absence of overarching authority, and the distribution of capabilities among states. The neo-realists believe that, those capabilities define a state's position in the system. That is to say that, in pursuit of their interest, states will attempt to exploit resources, and therefore, relations between them are determined by state's military and economic capabilities (Arabu, 2016: 44). To neo-realists, the international system, though it emerges from the interactions of states, it is a force of its own that forcefully constrains state behaviour and state in response may not be able to control it (Donelly, 2005: 35). Thus, the neorealist emphasised that the international structure is the determinant of outcomes rather than the individuals.

Of great significance is the neo-realists' position with regards to the relationship between states. Indeed, the balance of power among nations, which they believe is largely determined by the structure of the international system (uni-polar, bipolar or multi-polar, as the case maybe), is one of their core principles. To neo-realists, balancing of power, rather than bandwagon is the essential in an anarchical international system: 'in hierarchic political orders, actors tend to jump on the bandwagon of a leading candidate or recent victor because loosing does not place their security in jeopardy' (Donelly, 2005: 35). To Bandwagoners, siding with a stronger party would mean attempt to increase their gains or reduce their loose. In an anarchical system, however, this could be a great mistake because it would mean strengthening someone who may later turn against you. As such, great powers attempt to reduce their risk by opposing stronger party (Donelly, 2005: 35).

As for weak states, they have little choice but to guess right and hope that early alignment with the victor would bring favourable treatment. Only foolish great powers would accept such a risk. They, instead, will balance, both internally, by relocating resources to national security and externally, primarily through alliances and other formal and informal agreements (Donelly, 2005: 36).

Indeed, in an anarchical system, one has to think of the possibility of cooperation and relative gains among states, since no matter how cunning a state maybe, it cannot stand in isolation. For the neo-realists, the possibilities for international cooperation in an anarchical international system are logically slim. This is because anarchy and egoism greatly impede cooperation. And the prisoner's dilemma is there to formally offer a representation of this logic. 
Imagine two criminals taken in separately by the police for questioning. Each is offered a favourable plea bargain in return for testimony against the other. Without a confession, though, they can be convicted only of lesser crime. Each must choose between cooperating (remaining silent) and defecting (testifying against the other). Imagine also that both had the following preference ordering: (1) Confess while the other remains silent; (2) both remain silent; (3) Both confess; (4) Remain silent while the other confesses. Assume finally that their aversion to risk takes a particular form: they want to minimize their maximum possible loss. Cooperating (remaining silent) rewards both with their second choice (conviction on the lesser charge). But it also leaves the co-operator vulnerable to worst possible outcome (serving a long- prison term and knowing that your partner put you there). Each can assure himself against disaster by confessing (defecting). The rational choice is thus to defect (confess) even though both know that they both could be better off by cooperating. Both end up with their third choice, because this is the best way to assure that each avoids the worst possible outcome. (Donelly, 2005: 37).

In this case, 'conflict does not arise from any special defect in the actors'. Although they are selfish, they are not particularly evil or violent. Both are far away from even desiring conflict and actually prefer cooperation. Also, they are not ignorant or ill-informed: 'in an environment of anarchy, even those capable of mastering their own desires for gains and glory are pushed by fear towards treating everyone else as an enemy' (Donelly, 2005: 37). In fact, Mingst added that even when two states are faced with the possibilities for mutual or relative gain, the one that feels insecure asks how the gain will be divided. Such questions would be asked as will both of us gain? And if yes, who will gain more? (Mingst, 1999: 77). Indeed, following structural realism were quite a number of other interpretations of the Realist Tradition. Robert Gilpin, the author of War and Change, for example, added to the already known principles of realism, 'the notion of dynamism, of history as a series of circles - circles of birth, expansion and demise of dominant powers. Using an economic model, he explained the possibilities for the decline of powers, thus: 'the increasingly marginal returns of empire, a state level phenomenon; the tendency for economic hegemony to consume more and invest less, also a state level phenomenon; and the diffusion of technology, a system level phenomenon through which new powers challenge the hegemony' (Mingst, 1999: 78). And through Ann Tickner and her colleagues, gender and by extension, complexity was added to the Realists Tradition. Against Classical Realism, which is based on the notion of human nature and power, Tickner argues that human nature is not static and inalterable. Rather it is multidimensional and contextual. She argued that realism must be reoriented to forsake the narrow understanding of power as solely an affair of control and domination, to that which means 'the ability to act in concert (not just conflict), or to be in a symbiotic relationship (instead of outright competition)' (Mingst, 1999: 78-79).

In a nut shell, to sum everything up on the vast and in-exhaustive explanation of realism as a theory is to sum up the ideology of the realist thinkers in the following words. First, that the key actors as argued by this theory are the international system and the state. Secondly, that the individual (state) is viewed as power seeking, selfish and antagonistic. Thirdly, that the state is viewed as power seeking, unitary actor and has national interest to be promoted and protected. Fourthly, that the international system is characterised by anarchy and stability in balance of power system. And then, anarchy allows and even encourages the worst aspects of human nature to be expressed in International Relations and statesmanship in this regard thus involves mitigating and managing, not eliminating conflict, seeking a less dangerous world rather than a safe, just and peaceful one.

\section{Some Contributions of the Realists to the Understanding of International Relations}

At this juncture, it is pertinent to understand from what has been discussed so far, that Realism as a distinctive school of thought is a construct of the $20^{\text {th }}$ Century. What has been dubbed 'Classical Realism' is merely an assemblage of the thoughts of some classical philosophers in whose works, the basic themes of Realism are found; though such philosophers had never consciously unite themselves under the rubric 'Realism'. The resurgence of Realism in explaining International Relations and, specifically, international politics in the $20^{\text {th }}$ Century, was as mentioned earlier, spearheaded by Carr, Morgenthau etc., This, as identified earlier, was in re-action to the predominance of Liberalists traditions, which mounted its heydays in the mid-20 ${ }^{\text {th }}$ Century, in explaining international politics. This will be better understood when some brief insights are provided on the history of international politics in particular, and International Relations in general.

In its modern context, international politics started taking the steps to culminate in its present form roughly around the $17^{\text {th }}$ Century. This could specifically be identified with the Treaty of Westphalia in 1648 , which not only ended the 30 years' war in Europe but also ensured the development of territorial sovereign states (Elias and Sutch, 2007: 6). With this, it was believed that wars and conflicts would be erased as part of the defining features of international politics. Nevertheless, for about three and a half centuries after the Westphalian Treaty, many events have occurred and enormous issues unfolded in the international arena. Some of the major among these include

The progressive secularization of world politics, the development of the principles and instruments of international law, and the generation of international governmental organizations, from the ad-hoc Congress of Vienna (1815), to the League of Nations (1919) and the UN (1945)... (Elias and Sutch, 2007: 6)

One may also add to the list the following: colonisation and decolonisation of Africa, Asia and Latin America; the First and Second World Wars; the Cold War; the New World Order and the clashes of civilisations with its attendant terrorist movements; the rise of non-governmental international organisations; globalisation; and even the changing nature of the International System, which before 1945 was multipolar, eventually became bipolar from 1945 to the early 1990 s and finally transformed to become unipolar from 1991 to date (2020). Added to these are the relentless efforts of some dominant powers towards shaping international politics to dance to the tunes of their ideologies and agendas, as well as the efforts of historians and other analysts in explaining the nature of International Relations based on their personal 
moral judgements. In all these, especially from the 20th century, the Liberal project or agenda has been on the lead (Elias and Sutch, 2007: 42). It was thus; in response to this that the Realists rose to challenge what they refer to the Liberalists utopianism, which was dominating the landscape especially during the post-war years. Indeed, the Realists were able enormously influence the study of International Relations.

Realism, as could be observed from the previous sections of the paper, is a cut-clear, 'no-nonsense' approach to the understanding of international politics. It perfectly explains some of the basic themes of international politics to match the real happenings in the world. The basic feature of Realism has been focus on realities and avoidance of rhetorics and utopianism. This accorded the Realists with a powerful foundation to build-up on. For example, challenging Liberalism as an agenda that was formulated with the sole aim of reaching or justifying some ends, Elias and Sutch (2007: 42), noted that:

Carr's critique of inter-war liberalism shows that the concerns for peace and justice articulated by Wilson, Eden and Briand were articulations of the national interest of the victorious allies and that the enlightenment ideals of cosmopolitanism and humanitarianism, upon which their liberalism was based, were, when they were developed in the seventeenth and eighteenth centuries, themselves plans to perpetuate an international status quo favourable to the French monarchy.

It is observable here that beyond the tradition of being carried away by idiosyncrasies in the analysis of issues, Carr attempted to clearly lay bare, the realities surrounding the issue under scrutiny, i.e., the Liberalist agenda. This is identifiable with most other Realists. Moreover, even when the Realists identified the States as the basic actors, who control power in the International System, and also dubbed the roles of International Organisations and 'international law' among other international actors and factors as 'secondary', the call was basically to be realistic. This is because the Realists believed that although it could be argued that International Organisations, international law, etc. has enormous influence over international politics, these phenomena actuallyoperate in terms of power of the States. Another important attribute to the Realist theory of International Relations lies in its explanations of some core concepts that served as a kind of brochure for understanding statecraft. Such concepts include, among others, strategies for gaining power, the nature of security dilemma in world politics, balance of power, etc. (Elias and Sutch, 2007: 42-44)

\section{A Critique on the Thoughts of the Realist Thinkers}

From the foregoing, it is understandable that Realism has been a dominant theory since the conception of International Relations as a discipline. This is because it was able to provide an important framework for the understanding of so many international events as they happen. However, a critical assessment of the views of the realist thinkers in international relations would always leave the assessor with several unanswered questions as well as so many ambiguous issues. Quite alright, even if one is to criticise the theory, he would have to acknowledge its basic components. Nevertheless, it is observable that in at least three major significant respects, the theory lacked adequate precision and rigour. First of all, realists like Morgenthau have established their views of human nature pessimistically. They argued that human nature of egoism and lust for power itself, rather than faulty institutions, as argued by the liberals, were responsible for the misuse and temptation of power. In line with this negative view of human nature, the realists rejected the major values of the liberals' postulations on International Relations, including faith in a natural harmony of interests among states, in collective security enforced by international organizations, in pacifism, in peace without war, and in simple identifications morals and politics. Perhaps, the modern realist shifted their focus from human nature to the framework of international system in order to avoid such pessimism.

Secondly, Realism has been relatively static and even confined within a limited circle of thought. In terms of international interactions, it limited most views within the confines of power politics among nations. In terms of human nature, it remained so simplistic to label human behaviour to be confined within the boundaries of egoism and selfishness. In these and quite a number of other senses that are too numerous to be mentioned here, realism fails to capture the extent to International Relations and human nature and behaviours are both dynamic and diverse. In actual sense, international politics and relations are a different dialogue of voices and perspectives. In a nutshell, realism does not capture all of International Relations or even most of its important aspects, it overlooks or ignores many significant dimensions of international life. For instance, economic dimensions of international interactions, (e.g. international businesses) are overlooked. Additionally, the theory does not take into cognizance, cooperation, as an essential dimension of the flexibilities of human psychology and nature. Rather, they label man as un-cooperative and greedy. \

To finish, Realism ignores or at least overlooks other important actors in International Relations. Beside states and international system structures, the Realists consider all other actors with less significance than they deserve. Whereas Realism believes in alliances among states with similar interests to collaborate and pursue a certain interest, it views any effort towards cooperation to be bleak and even holds that such collaborations could end as collaborators could turn against each other after attaining the goal for which they aligned. Realism, therefore, denies the centrality of International Organisations in International Relations. In actual sense, however, International Organisations such as the United Nations Organisation (UNO), the European Union (EU), Northern Atlantic Organisation Treaty (NATO), as well as other Non-Governmental Organisations (NGOs) have been very influential in international interactions both directly and indirectly. One could take the influence of the UN in the creation of Israel in 1948, as well as the use of its instrumentality by the US to invade Iraq, leading to the First Gulf War in 1991. Moreover, the prevalence of International Organisations has proved that to a considerable extent, cooperation instead of conflict can prevail.

However, it is worthy to note that these are not the only possible criticisms of the views of realist thinkers, but they are among the important ones. There are other plentiful criticism that are too numerous to be mentioned here. 


\section{Conclusion}

In conclusion, this paper attempts to provide a clear synopsis of Realism as a theory. It discusses the meaning of Realism as a theory and doubles to present and discuss the thoughts of the major Realist thinkers. From the discussions so far, one has to admit that Realism is not only an ancient philosophical tradition, but have over the centuries been improved and regulated by different analysts and thinkers. It is, therefore, an original framework through which some essential aspects of human nature and international relations could be understood and analysed. However, from the discourses articulated in the previous section of this paper, it is understandable that the theory is not flawless.

Therefore, as observed by Donelly (2005:53) since Realism, just like other theories of International Relations is not always correct on most of its explanations of international interactions, one cannot rely solely on it to explain International Relations. Realism, he cautioned, 'must be part of the analytical toolkit of every serious student (and analyst or practitioner) of International Relations'. He however, added that, 'if it is our only tool - or even primary tool - we will be woefully underequipped for our analytical tasks, our vision of international relations will be sadly impoverished, and, to the extent that theory has an impact on practice, the projects we undertake in the world are liable to be mangled and misshapen'.

\section{References}

i. Abel, D. C. (2004), Fifty Readings in Philosophy, Second Edition, New York, Mc Graw Hill.

ii. Alkali, R. A. (2003), International Relations and Nigeria's Foreign Policy, $2^{\text {nd }}$ edition, Kaduna, Northpoint Publishers.

iii. Arabu, M. L. (2016), 'A History of Nigeria-Niger Relations: 1903-1998', PhD thesis, Department of History, UDUS.

iv. Arabu, M. L. (2018), 'Critical Reflections on the Relevance of Theories and Concepts in International Relations', Degel Journal of the Faculty of Arts and Islamic Studies, Vol. 14

v. Britannica, (www.britannica.com/biography/Hans-Morgenthau), Retrieved, 10/02/2020.

vi. Burchill, S. \& Linklater, A. (2005), 'Introduction', in Burchill, S. et. al.,Theories of International Relations, Hampshire, Palgrave Macmillan.

vii. Carr, E. H. (1984), What is History?Harmondsworth,Penguin Books.

viii. Donelly, J. (2005), 'Realism', in Burchill, S. et. al.,Theories of International Relations, Hampshire, Palgrave Macmillan.

ix. Elias, J. and Sutch, P. (2007), The Basics of International Relations, New York, Routledge Taylor and Francis Group.

x. Mingst, K, (1999), Essentials of International Relations, New York, W. W. Norton \& Company Inc.

xi. Moore, B. N. \& Bruder, K. (2005), Philosophy: The Power of Ideas, New York, Mc Graw Hill.

xii. Palmer, N. D. \& Perkins (2005), H. C., International Relations, $3^{\text {rd }}$ edition, New Delhi, AITBS Publishers.

xiii. Palmer, R. R. \& Colton, J. (1978), A History of the Modern World, New York, Alfred K Knopf.

xiv. Sharp, P. (2009), Diplomatic theory of International Relations, New York, Cambridge University Press.

xv. Strauss, A., The Political Philosophy of Hobbes: Its Basis and Its Genesis, London, Clarendon Press, 1963.

xvi. Yandaki, A. I. (2015), The State in Africa: A Critical Study in Historiography and Political Philosophy, Zaria, Gaskiya Corporation.

xvii. Deutsch, K. W. (1978), The Analysis of International Relations, Second Edition, New Jersey, Prentice-Hall Inc.

xviii. Morgenthau, H. J. (2012), Politics Among Nations, Revised by Kenneth W. Thompson, New Delhi, Kalyani Publishers. 